\title{
PHONETIC COMPETENCE FORMATION AND IMPROVEMENT OF TECHNICAL SPECIALTIES STUDENTS
}

\author{
Ustinova N. (Russian Federation) Email: Ustinova326@scientifictext.ru
}

\author{
Ustinova Natalia - PhD in Philology, Associate Professor, \\ LINGUISTICS AND FOREIGN LANGUAGES DEPARTMENT, \\ THE FACULTY OF SOCIAL AND HUMAN SCIENCES, \\ DON STATE TECHNICAL UNIVERSITY, ROSTOV-ON-DON
}

\begin{abstract}
The role of the phonetic competence in developing the foreign language communication competence is discussed. The definition, structures of the phonetic competence, its contents are given. The peculiarities and the main problems of the foreign phonetic competence formation and improvement of technical specialties students are analyzed. The varieties of tasks and methods for the study of foreign language pronunciation in the context of professional foreign language teaching have been suggested.
\end{abstract}

Keywords: phonetic competence, speech material, sound, phoneme, lexeme, system of exercises.

\section{ФОРМИРОВАНИЕ И СОВЕРШЕНСТВОВАНИЕ ФОНЕТИЧЕСКОЙ КОМПЕТЕНЦИИ СТУДЕНТОВ ТЕХНИЧЕСКИХ СПЕЦИАЛЬНОСТЕЙ Устинова Н.П. (Российская Федерация) Email: Ustinova326@ scientifictext.ru}

\author{
Устинова Наталья Петровна - кандидат филологических наук, доцент, \\ кафедра лингвистики и иностранных языков, социально-гуманитарный факультет, \\ Донской государственный технический университет, \\ 2. Ростов-на-Дону
}

\begin{abstract}
Аннотация: подчеркивается заинтересованность будущих специалистов технических вузов в изучении иностранного языка в условиях мировой интеграции. Дается определение фонетической компетенции. Исследуются особенности формирования, и совершенствования иноязычной фонетической компетеничи студентов технических вузов как составной части иноязычной коммуникативной компетенции. Обоснована специфика фонетики иностранной технической терминологии, выделены разновидности заданий и методы обучения иноязычному произношению в контексте профессиональноориентированного изучения английского языка.
\end{abstract}

Ключевые слова: фонетическая компетенџия, речевой материал, звук, фонема, лексема, система упражнений.

В наши дни особую актуальность в сфере развития высшей школы приобретает ее интегрирование в международное образовательное пространство, способствующее переосмыслению цели и задач изучения иностранных языков. Практическое владение иностранным языком является обязательным условием для ведения успешной профессиональной деятельности в условиях современного общественного развития, поэтому профессионально-ориентированному изучению иностранного языка отводится ведущая роль в разработке методов совершенствования уровня профессиональной языковой подготовки будущих специалистов.

Проблема языковой подготовки будущего специалиста технического вуза является значимой, так как результативность овладения сведениями иноязычной профессиональной направленности зависит от степени владения студентами иностранным языком. Следовательно, это приводит к необходимости развития навыков адекватного осознания терминов и определений в разных профессиональных областях, в связи с возрастающим количеством делового общения с коллегами по всему миру. Формирование и совершенствование основ иноязычной коммуникативной деятельности у студентов технических специальностей требует серьезного внимания к аспектам усвоения фонетических характеристик профессиональных лексем, к развитию способности слухового восприятия иноязычной коммуникации, выработке умений и навыков устного общения, чтения и понимания прочитанного материала, поскольку успешность речевой деятельности зависит от ясности и выразительности оформления общения с собеседником.

При изучении дисциплины «Иностранный язык в профессиональной сфере» под методикой формирования фонетической компетенции студентов технических специальностей понимают обучение произношению, направленное на выработку у будущих специалистов устойчивых орфоэпических навыков иностранного языка по профессиональному направлению.

Основной целью моего исследования является анализ системы фонетических упражнений и заданий, направленных на формирование и совершенствование умений произношения профессионально- 
ориентированных лексем студентов технических специальностей при изучении дисциплины «Иностранный язык в профессиональной сфере».

Авторы учебников и учебных пособий нового поколения по изучению иностранных языков технической направленности считают, что обучение устному профессиональному общению должно осуществляться посредством овладения всеми языковыми навыками (фонетическими, лексическими и грамматическими) с помощью различных предтекстовых и послетекстовых коммуникативных упражнений. Они же в свою очередь должны быть составлены на основе вербальных ситуаций и направлены на формирование и совершенствование правильного произношения профессиональных лексических единиц изучаемого языка, улучшение умений осуществлять коммуникацию и усваивать языковой материал, понимать текст, то есть всех тех навыков, от которых зависит успешное участие современного специалиста в профессиональном диалоге. Формирование фонетической компетенции студентов технических вузов осуществляется благодаря правильному произношению звуков и звукосочетаний, реализации орфоэпических норм в речевой деятельности, правильном акцентировании слов, владении интонационными средствами выразительности речи (темп, тембр, сила голоса, логическое ударение и т.п.).

Систематическая работа по улучшению произношения профессиональных лексем осуществляется студентами на протяжении всего курса изучения иностранного языка и выполняется на основе принципов преемственности обучения, поскольку студенты вузов изучают тот же иностранный язык, что и в школе, однако характер совершенствования их фонетической компетенции должен меняться на разных этапах обучения. На первых занятиях дисциплины «Иностранный язык в профессиональной сфере», целесообразным было бы повторить и систематизировать правила произношения, но опыт работы в группах студентов технических специальностей показывает, что часто ее нужно сформировать у студентов заново, потому что группы формируются из выпускников разных школ с неоднородным уровнем знаний. Такой коррективный курс фонетики требует значительных временных затрат, не предусмотренных программой учебной дисциплины. Работа над произношением в процессе изучения иностранного языка имеет большое значение для выработки умений и навыков устной речи, ведь возможность понимания иноязычного текста связана с адекватностью восприятия фонетической стороны речи и совершенствование обучения иноязычной речевой деятельности во многом определяется успешностью формирования произносимых основ этой деятельности [2, с. 29].

Стоит отметить специфику фонетики технической терминологии, лексемы которой имеют происхождение из латинского и греческого языков и активно применяются при изучении теоретических и практических учебных предметов. Будущие специалисты технических специальностей часто употребляют латинские термины вместо терминов, изучаемого языка, что связано с этимологией лексем: cell - cellŭla (клетка), centre - centrum (центр), fiber - fibra (волокно) и другие. Заинтересованность студентов в будущей специализации и активное сотрудничество между специалистами одного профиля будут способствовать формированию высокой мотивации студентов отрабатывать коммуникативную, в частности фонетическую иноязычную модель.

Существуют различные подходы к обучению иноязычной фонетики, однако, наиболее распространёнными являются традиционный и коммуникативный подходы. Суть традиционного подхода к изучению иноязычного произношения заключается в том, что обучение должно происходить как сознательное усвоение произносимых действий и их акустических эффектов. Становление слухопроизносительных навыков включает ознакомление со звуками иностранного языка, тренировку их произношения и применение приобретенных умений в устной речи и в чтении вслух и включает два вида упражнений: активное слушание образца и сознательная имитация [3, с. 68-69]. Коммуникативный подход изучения иноязычной фонетики отрицает традиционный метод, подчеркивая, что обучение произношению с первых занятий должно проходить в условиях реального общения, а «произношение должно», не прилагаться «к речи, а быть его основой, неразрывно связанной с другими компонентами обучения иноязычной речи - лексическими и грамматическими навыками» [1, с. 43-44]. Следовательно, необходимо сочетать традиционный и коммуникативный подходы при обучении произношению профессиональной иноязычной лексики студентов неязыковых вузов, поскольку использование только традиционного метода является неэффективным из-за его направленности на выработку только акустических и моторных навыков без учета коммуникативного аспекта. Коммуникативный подход, хотя и базируется на коммуникации, не преодолеет негативного влияния межъязыковой интерференции, если не будет пользоваться концепциями традиционного подхода для формирования орфоэпических навыков. Целесообразным и эффективным здесь является демонстрация звуков лексем, впоследствии отработка артикуляции и закрепление навыков звучания фонем в ситуациях речевой деятельности, показывая функциональную и коммуникативную ценность правильной орфоэпии.

Работа над произношением должна осуществляться во всех видах учебной деятельности с обязательным применением усвоенных правил фонетики, как в живой речи преподавателя, так и в аудиозаписях. Развитие нормативной речевой деятельности у студентов является сложным процессом, 
который состоит в ознакомлении, формировании и совершенствовании коммуникативных действий будущих специалистов с новым фонетическим материалом в профессиональных ситуациях речи, главным образом на уровне фразы/предложения, а впоследствии и текста, то есть развитие свободного общения в соответствии с нормами и правилами фонетической системы иностранного языка.

Фонетические упражнения облегчают обучение произношению иноязычных звуков и делятся в методике на две основные группы: упражнения на рецепцию и упражнения на репродукцию, которые взаимосвязаны и имеют задачу сформировать у студентов как слуховые, так и орфоэпические навыки [1; $2 ; 3]$. Упражнения на рецепцию - это некоммуникативные упражнения на узнавание, дифференциацию и идентификацию. Задание на узнавание и дифференциацию нового звука/звукосочетания среди других, отмеченного слова и состава выполняются на уровне отдельных слов или словосочетаний. Задача упражнений на идентификацию звуков - распознавать звук как известный по определенным характеристикам. Образцами таких упражнений могут быть: прослушать фразы, стихи, в которых новый звук; прослушать пары слов и определить в них одинаковые согласные или гласные звуки и тому подобное.

Упражнения на рецепцию целесообразно использовать при обучении произношению на всех ступенях обучения иностранному языку в школе, при изучении дисциплины «Иностранный язык» в университете, а также и при овладении основами профессионального английского языка на занятиях дисциплины «Иностранный язык в профессиональной сфере». Стоит уделить особое внимание учебникам и руководствам по обучению студентов технических специальностей, содержащие раздел «Вводнокоррективный курс» или «Грамматический справочник», что позволяет студентам повторить и закрепить фонетические и грамматические конструкции, изученные на школьных занятиях иностранного языка. В курсе дисциплины «Иностранный язык в профессиональной сфере» в вузах упражнения на рецепцию рекомендуется выполнять при усвоении нового материала и чтении вслух. Практическими будут также рецептивно-репродуктивные задания на имитацию единиц речи: некоммуникативные, условнокоммуникативные и коммуникативные. В процессе выполнения некоммуникативных упражнений целесообразно обращать внимание на определенные характеристики фонем (долготу, ударение и т.д.). Условно-коммуникативные задачи используют такие виды работы: имитация образца речи, подстановка слова в словосочетания и предложения, ответы на вопросы. Целесообразными для формирования фонетической компетенции будут и коммуникативные упражнения, которые, безусловно, берут за сопротивление рецептивные и рецептивно-репродуктивные (некоммуникативные и условнокоммуникативные) образцы.

Каждое занятие дисциплины «Иностранный язык в профессиональной сфере» в вузе охватывает профессионально-ориентированный текст и фонетический материал к нему, который можно использовать для формирования профессиональной коммуникации во время занятий в аудитории и в процессе самостоятельной работы студентов. Стоит подчеркнуть необходимость использования словарей в процессе обучения фонетики иностранного языка, поскольку орфоэпическая компетентность является фундаментом устного общения, поэтому использование дополнительного источника знаний - словаря должно сопровождать все этапы работы над изучением звучания иноязычного слова. С помощью словаря студент получает информацию о произношении звуков с транскрипцией лексемы. Как правило, каждый иноязычный текст предлагается студентам с перечнем профессиональных терминов к нему, данных с транскрипцией, с которыми студент знакомится впервые. Часто этот перечень недостаточен для студента и уместным будет использование будущим специалистом дополнительных источников для выяснения, как значения неизвестной лексики, так и ее правильного произношения. Для усвоения фонетических норм профессионального иностранного языка следует использовать фонограммы произношения звуков в терминах, аудиозаписи текстов, отдельных разговорных тем и диалогов, применять словари для проверки орфоэпических норм слов и словосочетаний с последующим применением их в устных высказываниях профессионального направления.

Для закрепления навыков произношения студентов целесообразно начинать занятия профессионального иностранного языка с фонетических упражнений, целью которых является «настройка» артикуляционного аппарата воспринимать иноязычную речевую деятельность. На вводном (ознакомительном) этапе изучения темы профессиональной направленности следует использовать несложные рецептивно репродуктивные задания, развивающие орфоэпическую практику и одновременно имеющие коммуникативную направленность, поскольку одним из видов работы является не только правильно произношение лексемы, но и составление с ней собственного выражения.

Опыт общения со студентами на занятиях дисциплины «Иностранный язык в профессиональной сфере» показывает, что мы часто наблюдаем тенденцию к употреблению латинских и греческих эквивалентов вместо слов, изучаемого языка. По этой причине студентам рекомендуют закрепить этимологию иноязычных лексем и реализовать орфоэпические нормы, выполнив условнокоммуникативные тренировочные упражнения репродуктивного характера. 
Совершенствование речевых действий студентов с фонетическим материалом на уровне словосочетания и предложения осуществляется с помощью заучивания наизусть профессиональных словосочетаний, устойчивых оборотов, стихов, диалогов, а также чтение вслух отрывков текстов из учебника и тому подобное. Обзор учебно-методической литературы профессиональной направленности позволяет сделать выводы, что авторы учебников активно используют вышеперечисленные коммуникативные конструкции для обучения фонетической компетенции, ведь студенту проще запомнить произношение определенного профессионального термина в контексте фразы или предложения, которые рифмуются.

Современные учебно-методические пособия предлагают такой вид работы как аудирование, которое активно применяется с целью выработки фонетической, лексической и грамматической компетенции. Будущие специалисты должны прослушать аудиозапись или посмотреть учебно-методический видеоматериал, воспроизвести и обсудить его с преподавателем и группой. Такое представление профессионального дидактического материала ориентирует студентов не на механическое запоминание большого количества иностранных профессиональных лексем, а на развитие речевой деятельности, то есть тех умений, которые необходимы для решения профессиональных ситуативных задач, используя иностранную терминологическую лексику. Правильное фонетическое звучание иностранного языка позволит будущему специалисту корректно произносить профессиональную терминологию в собственной коммуникации, поскольку каждое задание учебника или пособия для студентов технических специальностей направлено не только на проверку фонетической грамотности студента, но и на дальнейшее создание собственного устного текста, который должен быть понятен для собеседника.

Варианты фонетических задач отрабатывают коммуникативную модель обучения иностранному языку и используются, как правило, в системе предтекстовых упражнений, поскольку привлекают внимание студента к закреплению правильной фонетической коммуникации еще до этапа обработки аутентичного текста профессиональной направленности.

Процесс формирования и совершенствования иноязычной фонетической компетенции студентов на занятиях со студентами технических специальностей является неотъемлемой частью профессиональной культуры будущих специалистов, ведь практическое овладение иностранным языком невозможно без совершенного усвоения его произносимых структур. Для приобретения необходимых навыков, которые будут облегчать обучение иноязычному произношению целесообразно использовать две основные группы фонетических задач: упражнения на рецепцию и упражнения на репродукцию, которые взаимосвязаны в научно-практическом формате и имеют задачу сформировать у студентов слуховые и произносимые умения.

Чтобы преодолеть фонетические трудности при изучении дисциплины «Иностранный язык в профессиональной сфере» предлагаются различные упражнения и задания, которые построены на основе традиционного и коммуникативного подходов и направлены на выработку у студентов навыков произношения профессиональных иноязычных лексических единиц. Однако рассмотренные виды упражнений, безусловно, не исчерпывают глубину форм и методов работы со студентами при обучении иноязычной фонетики. Многие методы совершенствования навыков работы с произношением профессиональных лексем еще ждут своей разработки, как в теоретической, так и в практической областях.

\section{Список литературы / References}

1. Бужинский B.B. Работа над английским произношением на начальной ступени коммуникативного обучения иноязычному говорению // ИЯШ, 1991. № 4. С. 43-45.

2. Павлова С.В. Обучение иноязычному произношению на коммуникативной основе // ИЯШ, 1990. № 1. C. 29-32.

3. Рогова Г.В. Методика обучения иностранным языкам в средней школе / Г.В. Рогова, Ф М. Рабинович, Т.Е. Сахарова. // М.: Просвещение, 1991. 287 с. 